\title{
CULTURAL HERITAGE ABROAD: LITERACY FESTIVITIES, CELEBRATED IN THE EDUCATIONAL INSTITUTIONS OF BULGARIAN IMMIGRANT COMMUNITIES
}

\author{
Mariyanka Borisova \\ Institute of Ethnology and Folklore Studies with Ethnographic Museum, \\ Bulgarian Academy of Sciences \\ e-mail:mariyanka.borisova@iefem.bas.bg
}

\begin{abstract}
The paper aims to present the role of cultural heritage in the situation of migration. The different cultural, social, and economic environment in the host country poses an influence on migrants' cultural heritage. At the same time, the latter also exercises an impact: it stimulates the integration and the consolidation processes among the immigrant community and provides grounds for the personal and collective cultural identity. The consolidation of the immigrant community in institutions, such as schools, churches, associations, folklore groups, museums, choirs, results from the activity and manifestation of this identity, as well as from the immigration policies in the host society. The paper analyses the construction, maintenance and the promotion of cultural heritage in a foreign setting through the example of the school holidays in Bulgarian educational institutions abroad. In the conditions of immigration, the education of Bulgarian language, culture, traditions and history results from the social strategies
\end{abstract}


maintained within the family and within the immigrant community as a whole. The Bulgarian literacy feasts that are celebrated in schools of the Bulgarian community abroad, holds a special place in the calendar of festive events, shapes out as feasts of the entire community, and asserts the cultural identity of adolescents in the context of immigration, giving them new perspectives and popularising Bulgarian culture abroad.

Keywords: Bulgarian schools abroad, cultural heritage, cultural identity, literacy festivities, migrant community

Ongoing throughout the entire history, migrant processes reached great scale and intensity in conditions of globalization. The political changes at the end of the 1980s in Eastern Europe, the economic consequences, and the enlargement of the European Union became prerequisites for a series of emigration waves from the countries of the former Eastern bloc to the West. In particular, the Bulgarian immigration since late $20^{\text {th }} \mathrm{c}$. and the beginning of the $21^{\text {st }} \mathrm{c}$. (the so called "new" migration, which is economic and more rarely educational by type and of family type as a composition) is directed primarily to countries in Western Europe (France, Germany, the United Kingdom), Northern Europe (Scandinavia), Southern Europe (Spain, Italy, Greece), and in North America (the United States and Canada).

The Bulgarian immigrant community transfers to the respective destination, preserves, construes, valorises, transmits and promotes the Bulgarian cultural heritage in its different forms - language, history, festivity, literature, music, traditions. The different cultural, social, and economic environment in the host country poses an influence on migrants' cultural heritage. At the same time, the latter also exercises an impact: it stimulates the integration and the consolidation processes among the immigrant community and provides grounds for the personal and collective cultural identity. The consolidation of the immigrant community in institutions, such as schools, church municipalities, associations, cultural centres, folklore dance and instrumental groups, choirs, media, museums results from the activity and manifestation of this identity, as well as from the immigration policies in the host society. The aim of the paper ${ }^{1}$ is analysis of the construction, maintenance and the promotion of cultural heritage in a foreign setting through the example of the literacy holidays in Bulgarian educational institutions abroad. In the conditions of immigration, the education of Bulgarian language, culture, traditions, and history results from the social 
strategies maintained within the family and within the immigrant community as a whole. The Bulgarian literacy feasts that are celebrated in schools of the Bulgarian community abroad, holds a special place in the calendar of festive events, shapes out as feasts of the entire community, and asserts the cultural identity of adolescents in the context of immigration, giving them new perspectives and popularising Bulgarian culture abroad (Borisova \& Koulov 2017).

\section{The Bulgarian Schools Abroad}

The growing number and members of the Bulgarian migrant communities leads to the growing number of Bulgarian schools abroad (2009 - 125 Bulgarian schools abroad; 2017 - more than 330 Bulgarian schools abroad) (Dikova 2017). The Bulgarian schools abroad are among the priority migrant institutions for maintaining and transmission of Bulgarian cultural heritage. The idea of creating a school came from the immigrant community itself as a "grassroots phenomenon". The schools are registered in the host country as non-profit, non-governmental organisations. Subsequently, the National Program "Native Language and Culture Abroad" (established in 2009) at the Ministry of Education and Science and the 334 Ordinance of the Council of Ministers (introduced in 2011) marked the engagement of the Bulgarian state with financial, organisational and program support of the Bulgarian schools abroad (See Borisova \& Koulov ibid.). To be able to work under these programs, the Bulgarian schools abroad are required to have gained licence at the Ministry of Education and Science and to have their school curriculum approved by the Ministry as representing an abridged version of the curriculum for the respective school grade in Bulgaria. The disciplines taught are Bulgarian language and literature, history, and geography. These schools generally supplement the educational system in the host country and usually engage Bulgarian children on Saturdays or Sundays (rarely on other days of the week), which is a reason for their popular terming as "Sunday Schools". The name "Bulgarian Schools Abroad" is their publicly accepted and most widely spread name. Student attendance is voluntary and depends mostly on the will, support, and encouragement from the parents (See Gergova \& Borisova 2018). The Bulgarian schools abroad are located in school buildings of the host state or in buildings of other Bulgarian institutions (for example embassy, cultural centre, church). In rare cases, a special building is rented, used entirely for the needs of the Sunday school. 


\section{Theoretical Basis}

The methodology applied in this study includes observation, participant observation, and semi-structured interviews. Inquiries were used with students at Bulgarian schools abroad (Spain, the UK, Austria, Germany, Ireland) - treating different aspects of the Bulgarian cultural heritage, among which the issue of festivities at educational institutions. The inquiries were prepared by the team of the project "Cultural Heritage in Migration. Models of Consolidation and Institutionalization of the Bulgarian Communities Abroad" and were popularised during fieldwork research.

Conceptualising cultural memory, Jan Assmann drew the attention to feasts and rituals, which - through their repetition, ensured the reproduction of cultural identity (Assman 1997: 55). Ritual recurrence - writes Assmann, provides coherence to the group in space and time. Paying attention to the feeling of community during the feast, of shared values, and of ritual repetition, the study emphasises the perception of Bulgarian educational holidays as representative ones of the Bulgarian heritage abroad. At the same time, the Bulgarian schools abroad and the educational holidays organised in them are viewed in the light of transnationalism (Krasteva 2014: 146-162; Portes 2001: 181-194), as a "grassroots phenomenon", as long as they are initiated from the immigrant community itself.

\section{Literacy Holidays Abroad}

Festivities, as an element of the Bulgarian cultural heritage abroad, are performed in various migrant consolidation forms, while the schools focus on literacy holidays. The Bulgarian schools abroad function as educational, cultural, and social centres of the migrant community as a whole, and literacy festivity forms the cultural identity of adolescents. The educational festivities that are celebrated in Bulgarian schools in Bulgaria and abroad coincide: they include the opening of the school year, the Day of People's Enlighteners $1^{\text {st }}$ November, the Day of Bulgarian Education and Culture and of the Slavonic Alphabet $-24^{\text {th }}$ May, which is usually the last school day.

The beginning of the school year (Figure 1) in Bulgarian schools abroad is usually made in accordance with the time for the opening of the school year in the host state and rarely coincides with the beginning of the school year in 


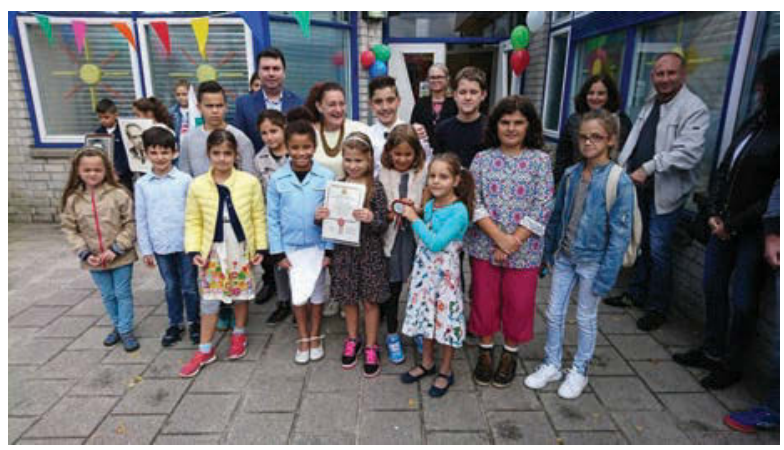

Figure 1. Opening of the school year at Bulgarian school "Ss. Cyril and Methodius", Leiden, Netherlands. $9^{\text {th }}$ September 2017. Photo by http://www.eurochicago.com/2017/09/layden/.

Bulgaria $-15^{\text {th }}$ September. The aim is that students would start their education simultaneously in the two educational systems. The feast is solemn and includes a range of characteristic symbols and rituals: the Bulgarian flag, the first school bell, plenty of flowers, the small cauldron with water, which is poured in front of the students as a wish for a successful new school year. The feast repeats the Bulgarian school rituals for the first school day, creates an environment that is close to the native one, and facilitates the overcoming of nostalgia for Bulgaria. Guests for the opening of the school year include parents, representatives of the Bulgarian community, Bulgarian diplomats in the respective state (ambassador, consul) who deliver greeting speeches and wishes for a successful school year. The Bulgarian children's choir with the school "Gergana" in New York organises a festive concert for the opening of the new school year, which coincides with the annual sessions of United Nations, which are attended with delegations from Bulgaria, including the President - who come to the school as honourable guests.

The Day of the People's Enlighteners on $1^{\text {st }}$ November was initiated as a state holiday, organised by the state authorities in 1922, which was a period of heavy national political and economic crisis in Bulgaria. The feast is dedicated to the Bulgarian educators revolutionaries, and cultural figures from the period of national revival. As is emphasised by Lina Gergova, "The feast was based on the memory (or the fear of losing the memory) about the heroes from the glorious 
recent past" (Gergova 2015: 13). Cancelled in 1950, the feast was restored in 1992. This discontinuity in the history of the feast did not permit the day to receive a wide-ranging public prominence, although it is a day without school classes. In Bulgaria, the Day of People's Enlighteners is opposed every year to the attractive celebrations of Halloween on $31^{\text {st }}$ October. The problem is not that much in the celebration of a non-Bulgarian, non-Orthodox holiday, but rather in the insufficient attention and only formal celebration of the Day of People's Enlighteners. Outside Bulgaria, this opposition disappears: celebrations for both Halloween and the Day of People's Enlighteners are often organised in the Bulgarian schools involved in the countries targeted in the project ${ }^{2}$. In the conditions of migration, the Day of People's Enlighteners is marked with school celebrations and lectures dedicated to the enlighteners (Figure 2). It is considered as an element of cultural heritage that needs to be preserved by the community. Portraits of the enlighteners are put at prominent places.

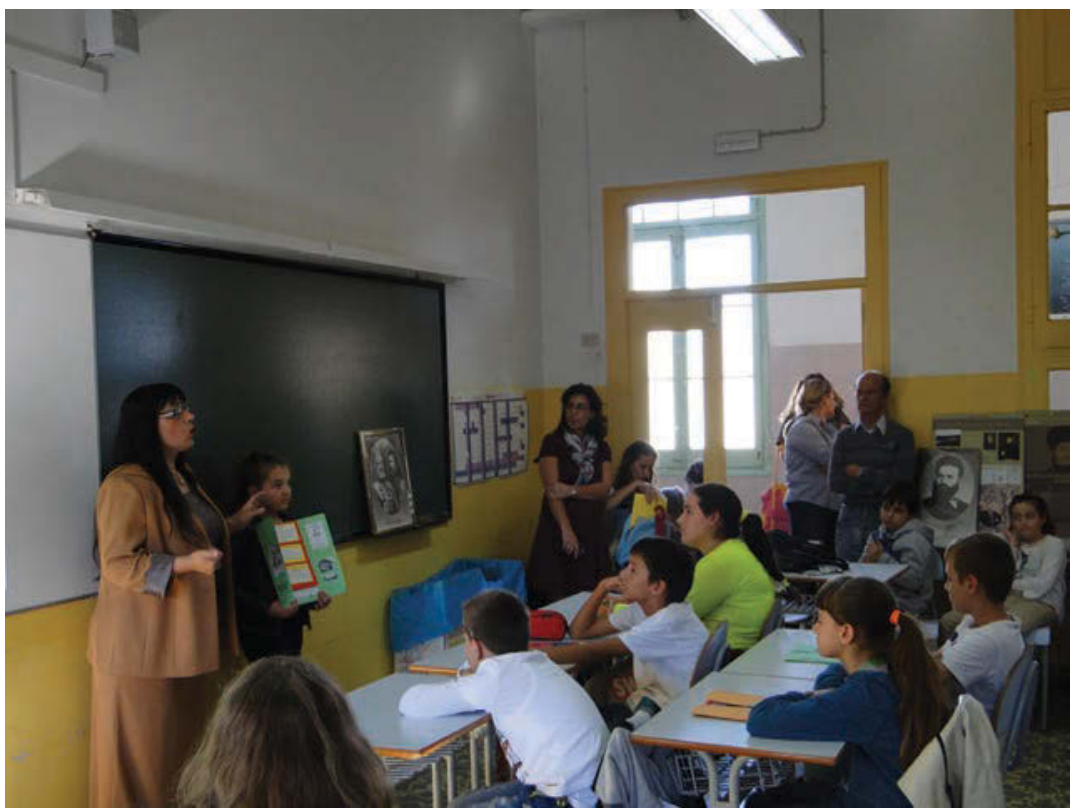

Figure 2. The Day of the people's enlighteners $1^{\text {st }}$ November 2015 at Bulgarian school "Ss. Cyril and Methodius", Barcelona, Spain. Photo by Nikolai Vukov. 
The lectures and discussions as a way of noting the day indicate that the holiday is still in the process of wide recognition, hence the knowledge about it needs to be repeated and affirmed. Thus, for example, the first significant event for "Ss. Cyril and Methodius" school in Rome after moving to the building of the Bulgarian cultural institute in 2014 was the celebration of the Day of People's Enlighteners. The celebration included an open class and a lecture from the ambassador of the Republic of Bulgaria to the Vatican and Malta, Prof. Kiril Topalov (Gergova \& Borisova 2015: 220). Asked to point out in the inquiries the most important holidays for the Bulgarians abroad, the children attending the Bulgarian schools in foreign countries, twice more rarely choose the $1^{\text {st }}$ November than $24^{\text {th }}$ May, even if they have the option of giving more than one answer. Both the fieldwork observations and the inquiries outline the Day of People's Enlighteners and its celebrations abroad as a feast in development, in gradual establishment.

The next educational feast, $\mathbf{2 4}^{\text {th }}$ May (Day of the Bulgarian Education and Culture and of the Slavonic Alphabet) is an emanation of the Bulgarian literacy festivities. It is dedicated to the holy brothers Cyril and Methodius - creators of the Slavonic alphabet and progenitors of the Church preaching in the Slavonic language. In its development, the feast passed through several phases - from a Church one through a school one, to a national and supranational one (the latter was manifested with the proclamation of Ss. Cyril and Methodius as Copatrons of Europe by Pope John Paul II in 1980. The feast owes its popularity to the fact that it was first celebrated in school environment even before the Liberation of Bulgaria from Ottoman rule (1878): its first celebration took place in Plovdiv in 1851. For Bulgarians, $24^{\text {th }}$ May gives ground for pride due to the hospitable welcome that the Medieval Bulgarian state provided to the deed of the two holy brothers. Bulgaria's civilising role in this respect was outlined on a state level already in the 1930s. Initially held in the church and school, the feast gradually opens up into the town square, where a procession of manifesting people carried portraits of the holy brothers decorated with flowers. During the socialist period, the manifestations for 24 May were particularly sober and colourful. After 1989, the manifestations, perceived as socialist heritage, were discarded. But in immigrant environment, these are perceived in some communities as Bulgarian cultural heritage, rather than as socialist heritage, and are practised in many Bulgarian schools. Thus, in 2015, "Little Bulgarian School" in Chicago (actually the biggest Bulgarian school in this city, with more than 400 students) noted the $24^{\text {th }}$ May with a festive procession. In 2017 four Bulgarian 
schools in Cyprus organised in Nicosia a joint manifestation for the Day of the Bulgarian Education and Culture and of the Slavonic Alphabet, at which the Bulgarian ambassador was also a guest. In all Bulgarian schools abroad the feast is noted with festive concerts, recitals, and greeting speeches (Figure 3). In 2015, at the initiative of the Association of the Bulgarian Schools Abroad and of Petya Tzaneva - founder and director of the First Bulgarian Sunday school "St. Ivan Rilski" in Madrid, a commemoration ceremony at the grave of St. Cyril in Rome took place on the $24^{\text {th }}$ May. Around 320 pupils, parents and teachers from eighteen Bulgarian schools abroad from eight European states took part in this ceremony (Gergova \& Borisova 2015: 221). The host of the initiative is "Asen and Iliya Peykovi" School in Rome, and the moments of culmination is the commemorative ritual at the grave of St. Cyril and the official visit to Pope Francis on "San Pietro" Square, which ended with singing

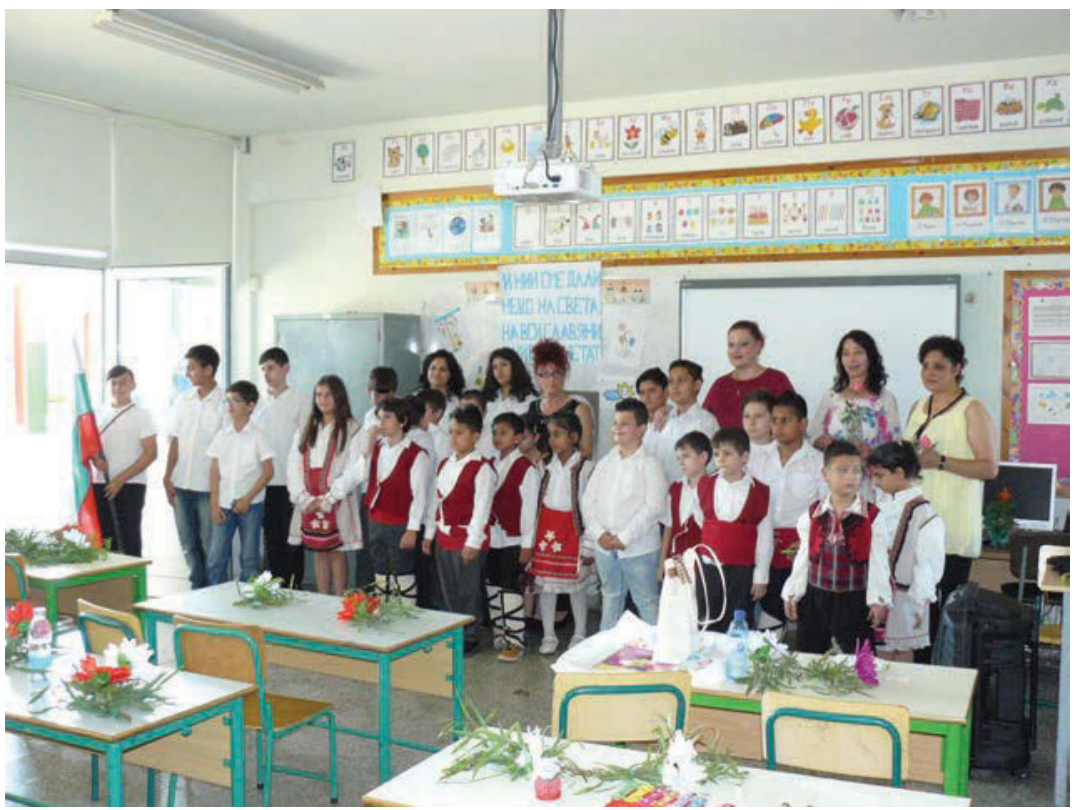

Figure 3. The celebration of $24^{\text {th }}$ May 2017 at "Paisiy Hilendaski" Bulgarian school, Limassol, Cyprus, 2017. Photo by Mariyanka Borisova. 
the hymn, dedicated to the holy brothers "Go Ahead, Revived People" and with dancing a Bulgarian traditional dance ${ }^{3}$. The Bulgarian schools abroad noted the special day with festive concerts and processions, with participation of large audience. Almost all school inquiries outline the $24^{\text {th }}$ May as being among the most honored Bulgarian feasts abroad. The special day is recognised as such not only by the people engaged in the educational institutions, but by the entire Bulgarian community. In the foreign environment, the day of Salonica brothers gained new power of consolidating the Bulgarian community and affirming the Bulgarian cultural identity through its links with Bulgarian literature and script, with Orthodoxy, and with the Medieval glory of the Bulgarian state.

The end of the school year for the Bulgarian schools abroad is also like an educational holiday as it marks the graduation of each class in the educational system. This holiday is also attended by external guests such as Bulgarian

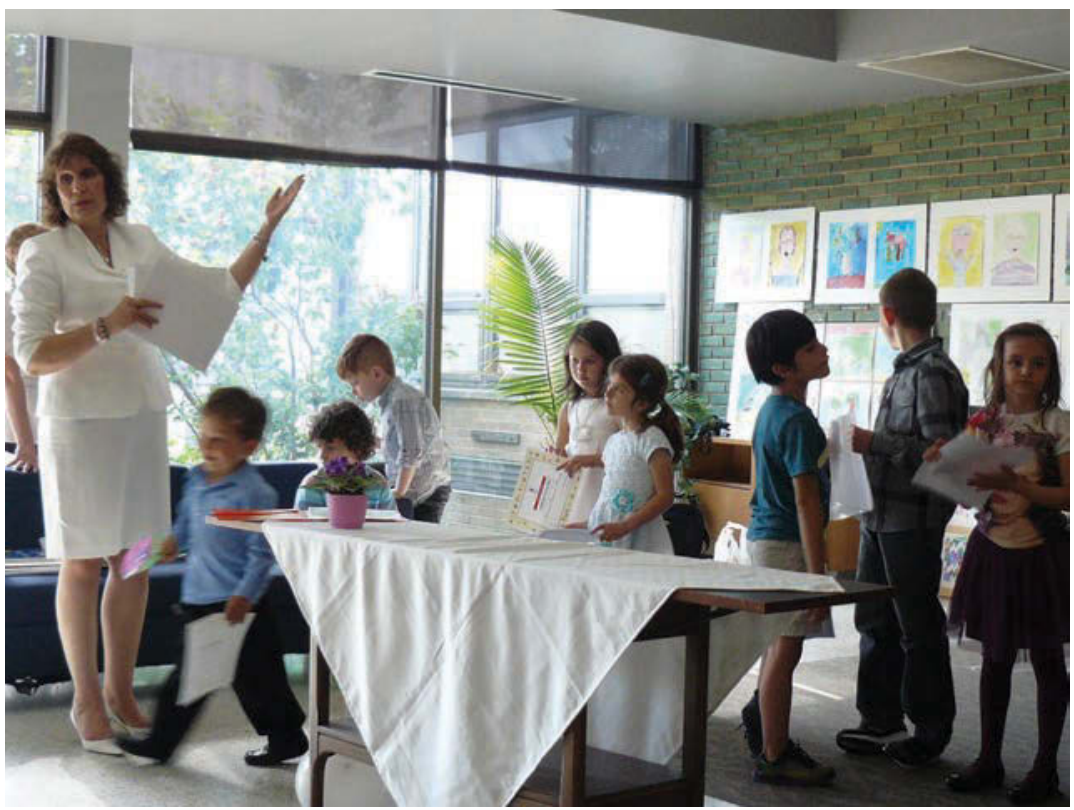

Figure 4. Bulgarian school "Rodolyubie" (Patriotism), Chicago, USA. The Day of Bulgarian Education and Culture and of the Slavonic Script in the schools abroad often coincides with the finale of the school year and the diplomas' awarding. $24^{\text {th }}$ May 2015. Photo by Mariyanka Borisova. 
diplomatic representatives (often ambassadors), who give students their certificates for the education they have received during the year. If it is a high school, there is held a ritual transmission of the school flag to the following class (as in the Bulgarian school "Hristo Botev" in New York, USA). The festivities include concerts, recitals, and theatre performances. They show what the students have learnt during the school year about the Bulgarian language, literature, music, and dances. The holiday is often organised in the open and attracts as its guests both parents and representatives of the Bulgarian community that are not linked directly with the school. In many Bulgarian schools abroad, the end of the school year coincides with the celebration on the $24^{\text {th }}$ May (Figure 4), as this happened in 2015 in Bulgarian schools "Rodna rech" (Native speech), "Rodolyubie" (Patriotism), "St. Sophia” in Chicago, USA.

\section{Conclusion}

The literacy holidays marked by the Bulgarian schools abroad are distributed in the course of the school year. The opening and the end of the year put a frame to the educational cycle; the Day of the People's Enlighteners is the culminating feast during the fall term, whilst the Day of the Bulgarian Education and Culture and of the Slavonic Alphabet is the culminating educational holiday for the entire school year. Both in Bulgaria and abroad, the school is the main host of educational festivities, as long as the educational and revival ideas that it embodies, are established first and mainly in the school environment (Gergova 2015: 10).

In the Bulgarian schools abroad, $24^{\text {th }}$ May gathers as audience a significant part of the Bulgarian community in the particular town and plays a powerful consolidating role. It gathers together the representatives of different Bulgarian immigrant associations and is a community holiday, one that affirms the school as an educational, cultural and social centre in conditions of immigration.

Informal and parallel institutions by presumption, the Bulgarian schools abroad get institutionalised through their registration in the host country and in Bulgaria; they function "with clearly defined administrative frames and hierarchies, with the entire array of mechanisms for power influence, but excluding the pending obligation, on which the mandatory secular education is based nowadays" (Gergova \& Borisova 2018). Through their educational festivities, the Bulgarian schools also seek additional legitimation from the Bulgarian state 
officials, sharing these festivities with the official representatives of Bulgarian state institutions at the particular destination.

The dances, the recitals, the language of the school holidays, the music, and the portraits of the celebrated personalities build the place as special, outside the mainstream of the dominant host culture (Hawkins 2007: 376). The manifestation of cultural identity outlines physical space, even if it is a temporary holiday space. Literacy holidays enhance the sense of the continuity of the cultural heritage of Bulgarian community abroad, enrich the adolescent and supply them with solid cultural identity, with a feeling of roots and belonging.

\section{Notes}

1 The current text is a part of the author's participation in the project "Cultural Heritage in Migration. Models of Consolidation and Institutionalization of the Bulgarian Communities Abroad" (2015-2017), financed by the National Science Fund at the Ministry of Education and Science of the Republic of Bulgaria.

2 Geographically, the project encompasses countries in Europe and North America.

3 http://www.eurochicago.com/2015/05/balgarskiyat-da-stane-maturiteten/, last accessed on 24.09.2017.

\section{References}

Assmann, Jan 2001. Kulturnata pamet [The Cultural Memory]. Sofia: Planet 3.

Ali-Knight, Jane \& Robertson, Martin \& Fyall, Alan \& Ladkin, Adele (eds.) 2008. International Perspectives of Festivals and Events. Amsterdam, Boston and others: Elsevier.

Borisova, Mariyanka \& Koulov, Boian 2017. Literacy Festivities outside the Homeland: Bulgarian Sunday Schools in Chicago. In: N. Vukov \& L. Gergova \& T. Matanova \& Y. Gergova (eds.) Cultural Heritage in Migration. Sofia: Paradigma, pp. 399-410.

Dikova, Tatyana 2017. Ot 15 septemvri v nad 330 nedelni uchilishta po sveta shte zvuchi Balgarska rech [From $15^{\text {th }}$ September in More than 330 Sunday Schools around the World Bulgarian Speech Will Sound]. Az buki, 29, 20.-26.07.2017.

Falassi, Alessandro 1987. Festival: Definition and morphology. In: A. Falassi (ed.) Time out of time: Essays on the festival. Albuquerque: University of New Mexico Press, pp. 1-10.

Gergova, Lina 2015. Denyat na balgarskata prosveta i kultura i slavyanskata pismenost i Denyat na narodnite buditeli - dva praznika na duhovnostta [The Day of Bulgarian 
Education and Culture and Slavic Script and the Day of the Bulgarian National Leaders - Two Feasts of Spirituality). In: E. Atanasova \& G. Lozanova \& St. Stanoev (eds.) Praznikat na Kiril i Metodiy. Prostranstva na duha [The Celebration of Cyril and Methodius: Spiritual Spaces], Vol. 2. Sofia: Paradigma, pp. 7-19. Gergova, Lina \& Borisova, Mariyanka 2018. Transmisiya na kulturno nasledstvo v migratsiya: modelat na uchilishteto (po materiali ot Nyu York, Saedineni amerikanski shtati) [Transmission of Cultural Heritage in Migration: The School Model (Based on Materials from New York, USA)]. Available at https://www.academia.edu/36038345/ТРАНСМИСИЯ_НА_КУЛТУРНО_ НАСЛЕДСТВО_В_МИГРАЦИЯ_МОДЕЛЬТ_НАУЧИЛИЩЕТО_ПО_ МАТЕРИАЛИ_ОТ_НЮ_ЙОРК_САЩ_.

Gergova, Yana \& Borisova, Mariyanka 2015. Cultural Heritage in Migration: Bulgarian Sunday Schools in Italy. Papers of BAS. Humanities and Social Sciences, Vol. 2, No. 3-4, Sofia, Prof. Marin Drinov Publishing House of BAS, pp. 215-229.

Hawkins, Michael C. 2007. Ethnic Festivals, Cultural Tourism, and Pan-Ethnicity. In: I. M. Miyares \& Ch. A. Airriess (eds.) Contemporary Ethnic Geographies in America. Lanham, Boulder, New York, Toronto, Plymouth, UK: Rowman \& Littlefield publishers, Inc., pp. 375-396.

Jepson, Allan S. \& Clarke, Alan 2013. Events and community development. In: R. Finkel \& D. McGillivray \& G. McPherson \& P. Robinson (eds.) Research themes for events. Wallingford: CABI, pp. 6-17.

Jepson, Allan S. \& Clarke, Alan (eds.) 2015. Exploring Community Festivals and Events. London \& New York: Routledge.

Karamihova, Margarita 2004. Americkanski mechti: Patevoditel sred parva generatsiya imigranti [American Dreams: Tour GuideofFirstGeneration Immigrants].Sofia:Crotal.

Koulov, Boian 2016. Balgarskite uchilishta v chujbina - istoriko-geografsko izsledvane. [Bulgarian Schools Abroad - Historical and Geographical Survey]. History, 24 (2), pp. 119-139.

Krasteva, Anna 2014. Ot migratsia kam mobilnost: politiki i patishta [From Migration to Mobility: Politics and Roads]. Sofia: New Bulgarian University.

Miyares, Ines M. \& Airriess, Christopher A. (eds.) 2007. Contemporary Ethnic Geographies in America. Lanham, Boulder, New York, Toronto, Plymouth, UK: Rowman \& Littlefield publishers, Inc.

Portes, Alejandro 2001. Introduction: The Debate and Significance of immigrant transnationalism. Global Network, 1 (3), pp. 181-194.

Vukov, Nikolai \& Borisova, Mariyanka 2017. The Festive Days of the Bulgarian Community in Chicago - Models of Cultural Heritage in Migration. Papers of BAS. Humanities and Social Sciences. Sofia, Prof. Marin Drinov Publishing House of BAS, Vol. 4, No. 1, pp. 18-37.

10 godini Asotsiatsia na balgarskite uchilishta v chujbina (2007-2017) [10 Years of the Association of the Bulgarian Schools Abroad (2007-2017)], 2017. Sofia: Anubis, Bulvest 2000. 